\title{
THE ODD WOMAN
}

\author{
Margaret Rutherford
}

\author{
John Stokes
}

Although Margaret Rutherford's (1892-1972) presence became familiar to an enormous public, she remained in her performances the odd woman out: at times 'difficult', yet irrepressible; peculiar in dress, mannerism, speech, yet invariably to the fore. With their predilection for physical detail, at best careless, at worst cruel, all too commonplace at the time, critics liked to make fun of her features: her trembling chins, pursed lips, popping eyes, her mobile eyebrows. She was certainly physically memorable. Her whole body seemed to invite comment, especially when on the move: clasped hands, large strides interspersed with sudden darts, a bustling and, at the same time, purposive gait. Over the years her costumes and props became standardised: umbrella, beads, spectacles (alternating with lorgnette, monocle, even binoculars), a capacious shawl (or shapeless cape) and, always to top it off, floral hats that seemed to lead a horticultural life of their own. Throughout her career reviewers turned to animal epithets to describe her, but they were strangely mixed: porpoise, dragon, moth. It's as if the journalists were competing not only among themselves but with the actress herself in their attempts to capture her presence in a single stroke.

Rutherford's origins were unusual. A significant number of the actresses who achieved prominence in the early twentieth century came from a theatrical background - a vocational advantage that had often led to early starts as a child performer. The father of Fay Compton (18941978), for instance, was the actor Edward Compton, and she was acting professionally by 1911; Nina Boucicault (1867-1950) was a member of a long-standing theatrical dynasty; Joyce Carey (1898-1952) was the daughter of the actors Gerald Lawrence and Lilian Braithwaite. Rutherford, by contrast, was born into a quite untheatrical family with a troubled 


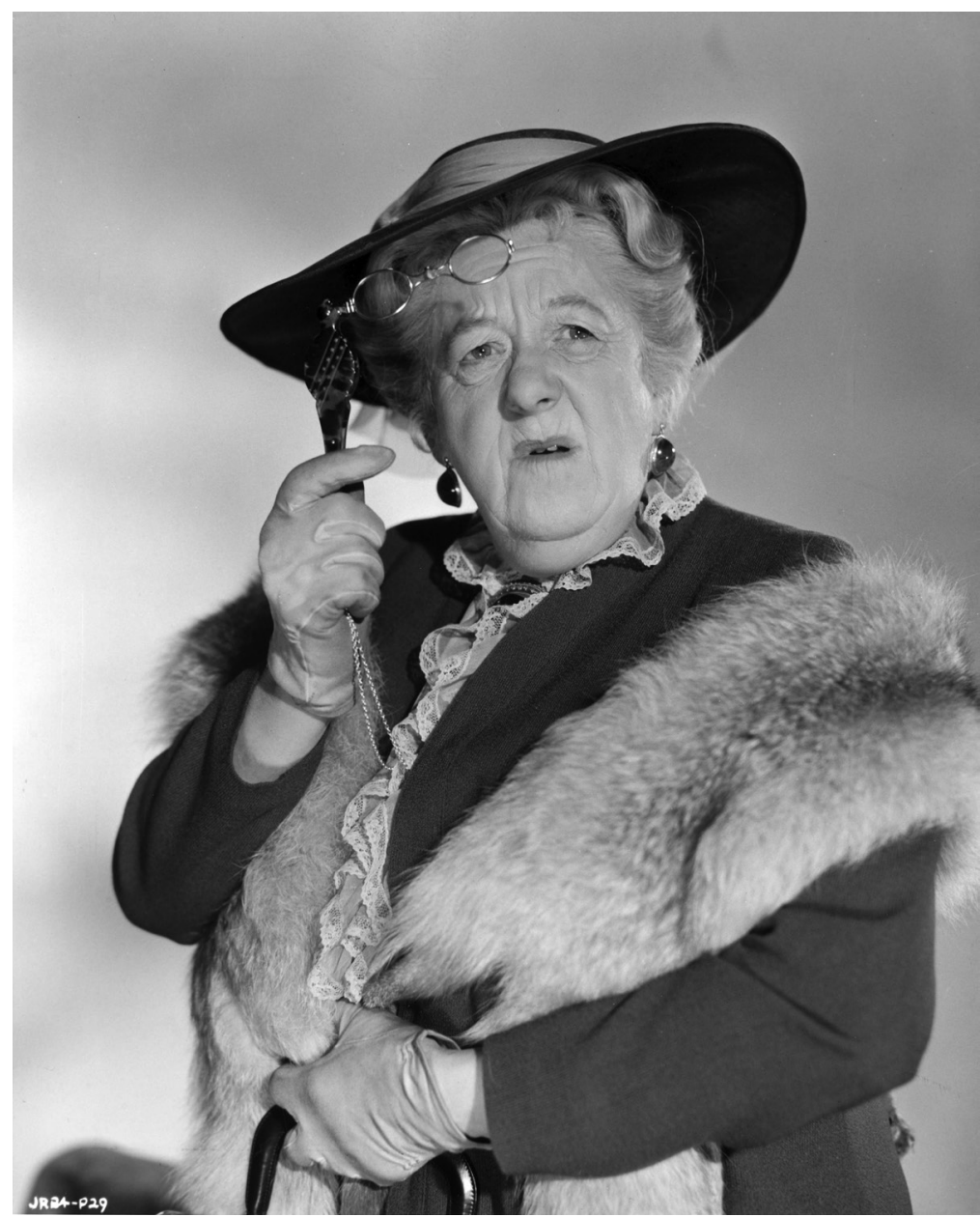

35 Margaret Rutherford as Aunt Dolly in I'm All Right Jack, 1959.

history - her father William, who worked as a journalist, suffered from a severely depressive illness that erupted at times into extreme violence. In 1883 he was found guilty of the murder of his father and incarcerated in an insane asylum until 1890. Two or three years after his release his wife, Florence, attempted to rebuild their lives in India, taking with them their baby daughter Margaret, who had been born in London in 1892. This period ended tragically when Florence killed herself. Margaret 
was not to learn the details of a doubly sad story until some time later. In the meantime, she was brought up in south-west London by an aunt and other relatives, attending first Wimbledon High School and then a boarding establishment on the south coast. Although the record of her appearances in school productions shows that she already displayed an interest in acting, her musical abilities were considered more suited to a respectable career and so as a young woman she became a piano teacher around Wimbledon. The desire to perform, however, would not be appeased: she trained as an elocutionist and took part in amateur productions. Eventually she persuaded Lilian Baylis to take her on as a trainee at the Old Vic, beginning with a string of non-speaking parts in the 1925/6 season. Let go by Baylis, she returned to the amateurs but managed to find employment - including the role of Madame Vinard in Trilby - at a number of repertory theatres in outer London and in Oxford.

When Rutherford finally began to attract attention, several actresses born within a very few years of her were already well established. Fay Compton had made her name in J. M. Barrie's Mary Rose in 1920; Gladys Cooper (1888-1971) had been a Gaiety Girl in the early 19oos and later did well in revivals ranging from Pinero's The Second Mrs Tanqueray to Peter Pan; Edith Evans, born in 1888, was by the 1920 s combining Shakespeare with major roles in Shaw and Congreve. For these women the main opportunities, apart from Shakespeare and the occasional classic, came from Coward, Maugham, Novello, Barrie and Shaw, major dramatists of the first three decades of the new century. Rutherford's progression would be rather different.

In one of her earliest West End appearances, Hervey House, a light comedy about an aristocratic ménage à trois at Her Majesty's directed by Tyrone Guthrie in 1935, Rutherford offered 'a most lively sketch of a troublesome aunt' (Avery, 1935: 15). The run was short but Rutherford's interpretation attracted some positive attention. Being older than the average newcomer made her an eligible candidate for such roles and in this case she replaced the more established Athene Seyler (1889-1990). In the same year, in a play by Robert Morley entitled Short Story, Rutherford confirmed her ability to represent the awkward element by giving 'a brilliant performance as the Gorgon of the village institute' (Brown, 1935: 22). By now she was 43 years old and several female performers significantly younger than her were already succeeding in the classical repertoire women such as Peggy Ashcroft (1907-91), Flora Robson (1902-84) and Celia Johnson (1908-82). Formal training had become much more available with the setting up of the Central School of Speech and Drama and 
the Royal Academy of Dramatic Art (Sutherland, 2007): Johnson and Robson trained at RADA; Ashcroft was a product of Central. In 1932-33 alone Ashcroft played six Shakespearean roles together with major parts in She Stoops to Conquer and The School for Scandal. By the mid-1930s she was Juliet to the alternating Romeos of Gielgud and Olivier, and participating in the increased interest in Chekhov with The Seagull. Johnson began with a role in Major Barbara in 1928 and took on Ophelia in 1929. Having first been directed by Tyrone Guthrie in Cambridge, Robson continued with serious roles in Shakespeare, Chekhov, Pirandello and, above all, Ibsen.

However one configures dates and careers, Rutherford's professional experience looks out of kilter with that of these, her peers. It was too late for her to be considered for youthful heroines, including Shakespearean heroines. When it came to casting, she belonged, if anything, with a handful of actresses older than herself, stylish women who had made their names before the First World War but who were available to take on mature roles which, more often than not, carried traces of a lively past. Lilian Braithwaite (1873-1948) made a name for herself as the hysterical mother in Coward's sensational The Vortex in 1924; Marie Tempest (1864-1942) starred in Coward's Hay Fever (1925) as an actress worried about her fading looks. The remarkable Mrs Patrick Campbell (1865-1940) played Mrs Alving in Ibsen's Ghosts in 1928; Irene Vanbrugh (1872-1949) played Shakespeare's Gertrude in 1931. Significantly enough, these tended to be maternal roles, passionate women burdened with difficult children. Rutherford's unglamorous style, coupled with her late start, would oblige her to establish herself as a 'type' outside the immediate family circle and yet omnipresent within the modern world. It would be, in every sense, a creative challenge.

When, much later on in her career in 1960, Rutherford appeared in a not very well-regarded play, Farewell, Farewell, Eugene, the Observer critic wrote of her ability to convey 'illumination through extravagance'.

Miss Rutherford - it's time to say it - is not only a great comic but a great actress. I know that she acts in a highly personal manner. Yet what we see is not Margaret Rutherford, the actress, but a woman of the Margaret Rutherford type, and in real life there are women we can only describe by referring to her. If acting can be called creative here surely is a high example. (Jones, 1959: 22)

Unlike a good deal of critical commentary, this is actually very helpful, because it encourages us to consider the ways in which a unique type 
might enable us to comprehend 'real life'. Of course, when thinking of a 'type' we shouldn't expect absolute consistency, since roles are chosen by agents, producers, directors, who will sometimes simply aim for repetition of known ability, but at other times will opt for more nuanced casting, playing games with established characteristics and occasionally deliberately casting against them. Not that there was anything passive about Margaret Rutherford, nor about the roles that she chose to play. For all her recognisability, at no point did she simply become the creation of manipulative producers, directors or, on occasion, writers. Her biographers all suggest that she was an active force in selecting parts and, crucially, in deciding what to do with them. There are clear signs from very early on that, whenever she could, she opted for roles in which the woman was comically, even harshly, represented, at least on the surface, and then looked for an explanation. She was funny - sometimes sublimely so - because she always seemed to know why her character behaved as she did.

What, though, was the 'type' that Margaret Rutherford's performances made real? One answer takes us away from the theatre altogether, away from comedy, and to a quite different meaning of 'odd' that originated in the nineteenth century amid an increasing fear that women were now outnumbered by men, leading to a numerically 'odd' number of unmarried, and probably unmarriageable, females. The presence of these 'odd' women, sometimes referred to as a 'surplus', was explained as the result of an imbalance within the population as a whole: around the turn of the century statistics based on the census suggested that there were simply not enough men to go around. Of course, there always had been unmarried women, but the degree of social concern was new - in 1893 George Gissing actually published a novel entitled The Odd Women - and it was to increase, partly on the basis of supposed evidence supplied by the official census, partly for reasons less easy to identify. In 1821 the ratio of men to women was 1,000 to 1,036 ; in 1901 it was 1,000 to 1,068 (Jeffreys, 1985: 88-9). In 1911, although the ratio remained constant, the number of single women over 25 increased. Another and quite overwhelming factor was soon to come into play - the loss of countless young male lives in the calamity of the First World War. Now to the number of the 'odd' had to be added young widows, bereaved fiancés and girlfriends. Following the 1921 Census the figures that appeared in the press varied enormously - anything between one and two million 'surplus' women (Nicholson, 2007: 22-3). Of particular import was the fact revealed by the 1931 Census that a significant proportion, some 50 per 
cent, of the women who had been aged between 25 and 29 and unmarried in 1921 were still single a decade later (Nicholson, 2007: 70-1). For these women, spinsterhood looked very much like a permanent state.

What the figures claimed to show was one thing; how they were interpreted was another. It was all too easy to assume, perhaps fuelled by male fears of female autonomy, that the spinster was doomed to loneliness, frustration and failure and that she was invariably in a situation not of her own choosing, ignoring the possibility that she might have sought, and indeed found, sexual and social fulfilment outside of heterosexual marriage or that she might have preferred to direct her energies away from the family into creative or professional activities. Many feminist battles have been, and continue to be, fought over just such issues. Nonetheless, it was in this highly charged and prejudicial interwar climate that Rutherford developed and sustained her own persona by taking key roles in plays, written by both men and women, in which the figure of the spinster had an apparently marginal but, in fact, importantly functional role to play.

As Maggie B. Gale suggests in her study of women playwrights between 1918 and 1962, in plays of the period, the spinster was often, though not always, virginal, naïve or simply judgmental, thus becoming a comic figure or ideological device' (Gale, 1996: 174). She continues:

Thus what connects these various spinster types is the fact that they are often used as 'fill in' to the main plot for moments of comic relief or as a means of opposing one ideology with another. They share with many representations of single, working women, a defined series of characteristics, but are rarely the centre of narrative focus. (1996: 175)

This is true, but neither does the spinster disappear within the narrative altogether. Much of Rutherford's comedy depended on the paradoxical joke that although 'surplus', she was also somehow essential. Another way of indicating that paradox was to describe her as 'eccentric', a cliché that countless critics turned to throughout her life, that, indeed, she sometimes resorted to herself. Applied not merely to an unusual manner or lifestyle, 'eccentricity' can be invoked more precisely as an indication of the position of the 'odd woman', at a distance from the 'centre' as it was occupied by the conventional nuclear family. Time and again the social centre cannot hold without her supplementary, her 'eccentric' presence.

One figure above all, a female identity in which Rutherford, following on from that 'troublesome aunt' in Hervey House, might be said to 
have specialised, brought a necessary element of asymmetry and incompleteness to what might otherwise have appeared to be an entirely idealised view of domestic life. This was the spinster aunt. In a remarkable essay on the nineteenth-century novel from Jane Austen to Henry James, Colm Tóibín has noted how the frequent absence of mothers is matched by the vital presence of women who either are or who act like aunts, relating this to the need for heroines to escape their immediate biological ancestors if they are to achieve any degree of independence. This does not necessarily mean that these aunts are always welcome agents. As Tóibín also says, they can be 'both kind and mean, both well-intentioned and duplicitous, both rescuing and destroying' (Tóibín, 2011).

The full distinctiveness of Rutherford's qualifications as a stage aunt became apparent when she created Bijou Furze in Spring Meeting by M. J. Farrell and John Perry, which opened at the Ambassadors in the summer of 1938, directed by John Gielgud. 'M. J. Farrell' was the nom de plume of Molly Keane, an Anglo-Irishwoman who had already published some seven novels specialising in a kind of semi-comic Irish Gothic, set among families preoccupied with hunting and other country pursuits, worried about their financial state, but oblivious to the political world around them. Spring Meeting belongs with this branch of the so-called 'Big House' genre, but at the same time it relates to family comedies such Noël Coward's Hay Fever (1925) or Dodie Smith's Dear Octopus (August 1938). In Spring Meeting a cantankerous and excessively parsimonious landowner, a widower, has two unmarried daughters: Joan is dangerously old still to be single, although she is in love with a former stable boy who is unsuitable in terms of class and because of his Catholic background. Baby, the younger woman, is much more lively and already desperate to catch a man. Sir Richard also has a spinster sister - Bijou, the part that Rutherford made her own. Bijou is middle-aged, snobbish, selfish, indolent and puritanical, though an inveterate punter. She bullies the girls with visions of a future much like her own present: 'at your age you should be done with all ideas of marriage. Settled down to mind the house and garden, and help in the parish like your aunts before you.' Bijou's place in the family is continually played off not only against her two nieces but against a louche divorcee, an old flame of Sir Richard's, who is over from England together with her son, on whom Baby has her eye, At the conclusion - increasingly farcical and fast paced - not only are Bijou's nieces engaged to be married, but so too is Sir Richard. Joan and Michael must leave the Big House if they are to achieve independence, but the others will remain, prepared to take the risk despite the 


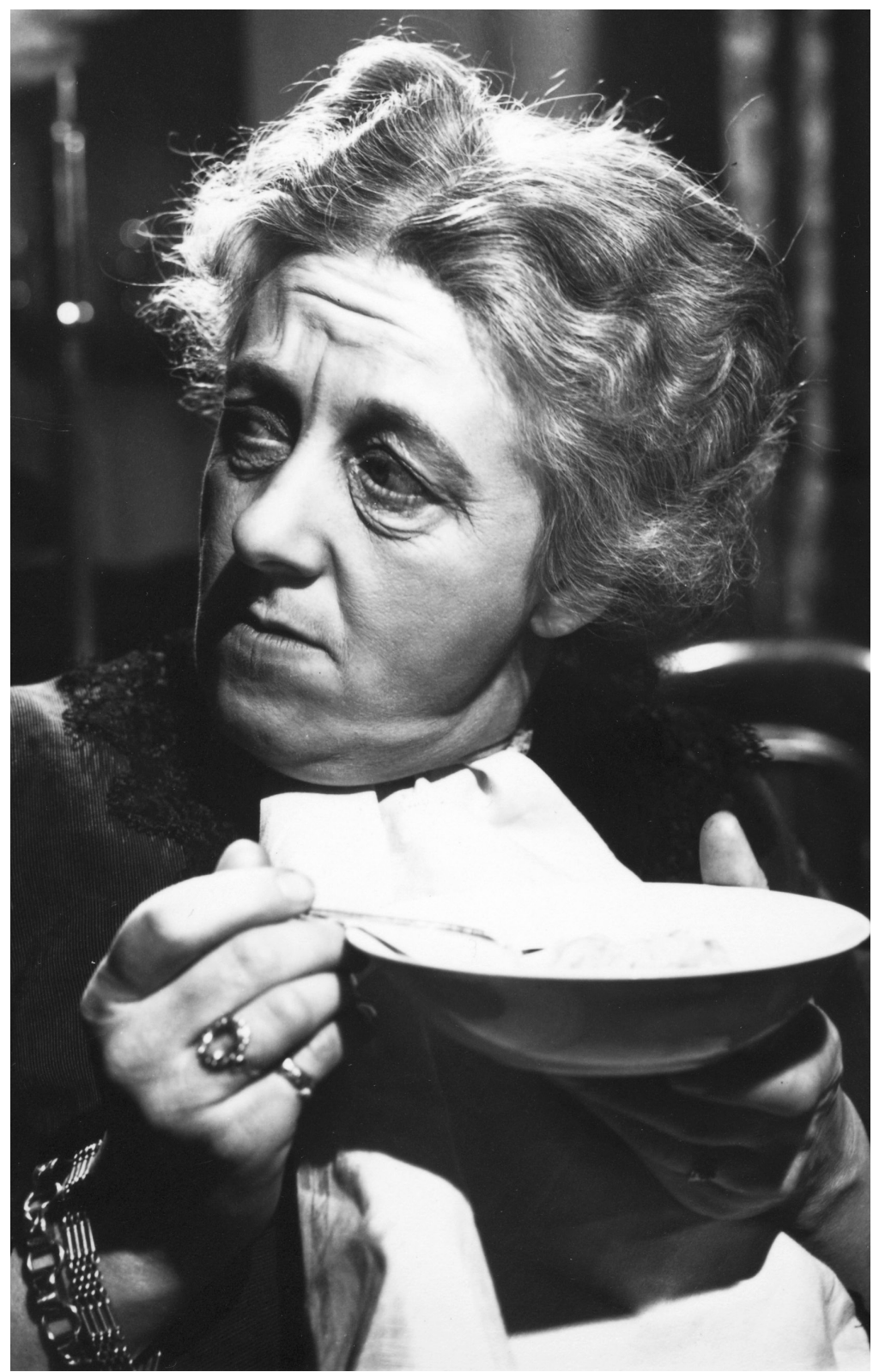

36 Margaret Rutherford in Spring Meeting, 1938. 
threat of penury. Bijou, too, will stay on, unmarried but linked to the family unit through a shared love of the turf.

Bijou Furze made a notable impact because Rutherford found depths - not always pleasant - in what remained in many ways a grotesque creation. For all that they readily invoked Chekhov, Synge and Shaw, few reviews failed to focus their attention on her performance, speaking of it as 'a study which is both hilarious and almost painful in its pathological exactitude' (Agate, 1938:4) and noting 'the force and the pathos' (Brown, 1938: 11). Bijou, as the critics recognised and as Rutherford herself realised, is a social remnant, a member of the 'surplus' as pathetic as she is malevolent. Joan, the niece, recalls that after the war 'chaps were scarce'. James, the butler, remembers 'Miss Bijou when she was a young girl the same as yourself. I remember her as it were yesterday with a fine head of hair and a blue silk dress, and as light in her step as yourself. A lovely girl. And not a one to court her.' After all, if Bijou 'got a husband and family she wouldn't be the pitiful old lady she is to this day'.

Some said that when Rutherford came to play Miss Prism in Wilde's The Importance of Being Earnest the year after Spring Meeting, she brought to the role much the same quality of feeling as she had discovered in Bijou Furze. One critic wrote of 'the human, almost too hauntingly human Prism of Miss Rutherford' (Brown, 1939: 9). Rutherford herself later both denied and admitted the point, saying that although she never intended a similarity, it may have been that she saw in both characters 'a deep strain of loneliness, of withdrawal from the world', adding 'this I have always personally understood' (Rutherford and Robyns, 1972: 59).

The very fact that Rutherford is one of the few - Athene Seyler is another - to have played both Lady Bracknell and Miss Prism is some indication of her ability to match contraries. Bracknell is both aunt and mother; she is also a wife, although we hear very little about that side of her life. Prism would seem to be the quintessential spinster, although she does find romance at the end. Wilde plays havoc with our preconceptions, which made both parts ideal for Rutherford. Moreover both women are largely oblivious of the effect they are having on others - a tendency that is shared among several characters that Rutherford made her own in the 1930s. Solipsists all, they sail blithely ahead, pursuing their own goals.

There were three years between Bijou Furze and Madame Arcati, the highly 'eccentric' medium in Noël Coward's Blithe Spirit, which opened at the Piccadilly Theatre in 1941. This was in some ways a development 
out of Rutherford's mid-1930s roles, which Coward must have seen. As has often been pointed out since, and was, in fact, remarked upon at the time, Coward's 'improbable farce' came at a time when death was in the air.

Madame Arcati, as grotesquely gay an old party as ever gulped Martinis and fresh air in equal quantities, prior to materialising a tambourine. This part, superbly played by Miss Margaret Rutherford, is the saving of this farce about the dead because it keeps it away from fact and feeling, wildly ludicrous and so offering as Hamlet said of this own theatricals, 'no offence in the world'. (Brown, 1941: 7)

Such comments, though suited to 1941, are insufficient to account for the lasting appeal of Rutherford's performance as it is preserved in the film version released in 1945. The role of a spiritualist medium confirmed her unique ability to convey the ambiguities of what she herself called 'my usual dotty old lady stuff' (Rutherford and Robyns, 1972: 83). According to the $O E D$, 'dottiness' originally referred to an uncertain way of walking, suggesting either feeble-mindedness or someone who was away from their normal environment. By the 1920s, or perhaps earlier, it had become noticeably gendered. The touchstone here is P. G. Wodehouse, creator of Jeeves and Wooster and a great connoisseur of aunts, who provides the first dictionary citation for 'dottiness' as meaning 'eccentricity'. Certainly very little of that original meaning remained in Rutherford's performance, since her customary walk by no means implied a lack of direction and was extremely determined. Although undoubtedly 'dotty' in the more modern sense because she believes in the supernatural, Arcati has absolute confidence in her own intellectual and physical abilities. A keen cyclist, she has a habit of placing her hands behind her hips, hauling up her shoulders so that she quite literally 'puts her back into it'. Her very language is active, a matter of re-energised cliché: 'Rome wasn't built in a day', 'Hungry as a hunter', 'Chin up', 'Great Scott', 'Good hunting'.

Apparently Rutherford was at first unwilling to take on the role, not wishing to make fun of spiritualism. Later on Coward was to complain of her actual performance as 'fussy' (Merriman, 2009: 71-2). However, one or two reviews and the evidence of the later film suggest that it was out of these tensions that Rutherford created the role. If Arcati is a fraud, she is giving nothing away, and Rutherford imbues her with great vitality and an unexpected lightness. James Agate's review suggests that he may have known something about initial differences between author and actress 
- and comes down firmly on the side of the actress. 'Whether Miss Margaret Rutherford does or does not present the medium Mr Coward first imagined', wrote Agate, 'I neither know nor care.' He continued, 'nothing could be more wildly funny than this grotesque embodiment, now pursuing the humdrum of her craft as soberly as a monthly nurse, now orgulous and ecstatic in inspired flight, for which sofas and settees are made to serve as springboard - not metaphorically, but literally' (Agate, 1941: 2). This technical observation is borne out by many other Rutherford performances in which she rises from a sitting position, a technique she perfected as she got older. Indeed, it is revealing how often Rutherford was described as bird-like. The title of Coward's comedy may derive from Shelley's 'To a Skylark' ('Hail to thee, blithe Spirit!/ Bird thou never wert'), and may most obviously refer to the deceased but still flirtatious Elvira; in performance it could equally be applied to Rutherford's soaring presence.

In the films she made during and soon after the Second World War, Rutherford was almost invariably cast as a leader, a female equivalent of men in government or in the field. The Demi-Paradise (1943) has a flashback structure, from the wartime present to the immediately pre-war. A Russian engineer played by Laurence Olivier visits England to develop a revolutionary new ship's propeller, encounters the 'old' England, and watches it respond to desperate circumstance. Rutherford is a do-gooder, bossy and commanding, energetic but old fashioned, who collects for a children's charity and organises the town's annual historical pageant. At first the Russian accuses the English of 'living in the past' and being 'a bit sleepy', but eventually he discovers the solution to his propeller problem by gazing at a cup of English tea. The English throughout make the best of things. They don't give up, appreciate the value of a sense of humour, are warm and friendly beneath the surface and, above all, 'love freedom'. The first version of Rutherford's pageant features the Roman occupation of England, Elizabeth I, news of the Battle of Waterloo. The second version has all this plus a final march of international soldiers - Polish, Czech, Belgian etc. - with the Rutherford character exhorting her company: 'Forward March', 'Let Victory be Unveiled'. The obvious propaganda message is that it is in the interests of both the Russians and the English to become allies.

Russia features, too, in The Yellow Canary (1943), which opens in September 1940 somewhere in Russia, as a romantic Russian tells English sailors his story in flashback - it is essential to hark back to pre-war times in order to explain the present. Much of the remembered 

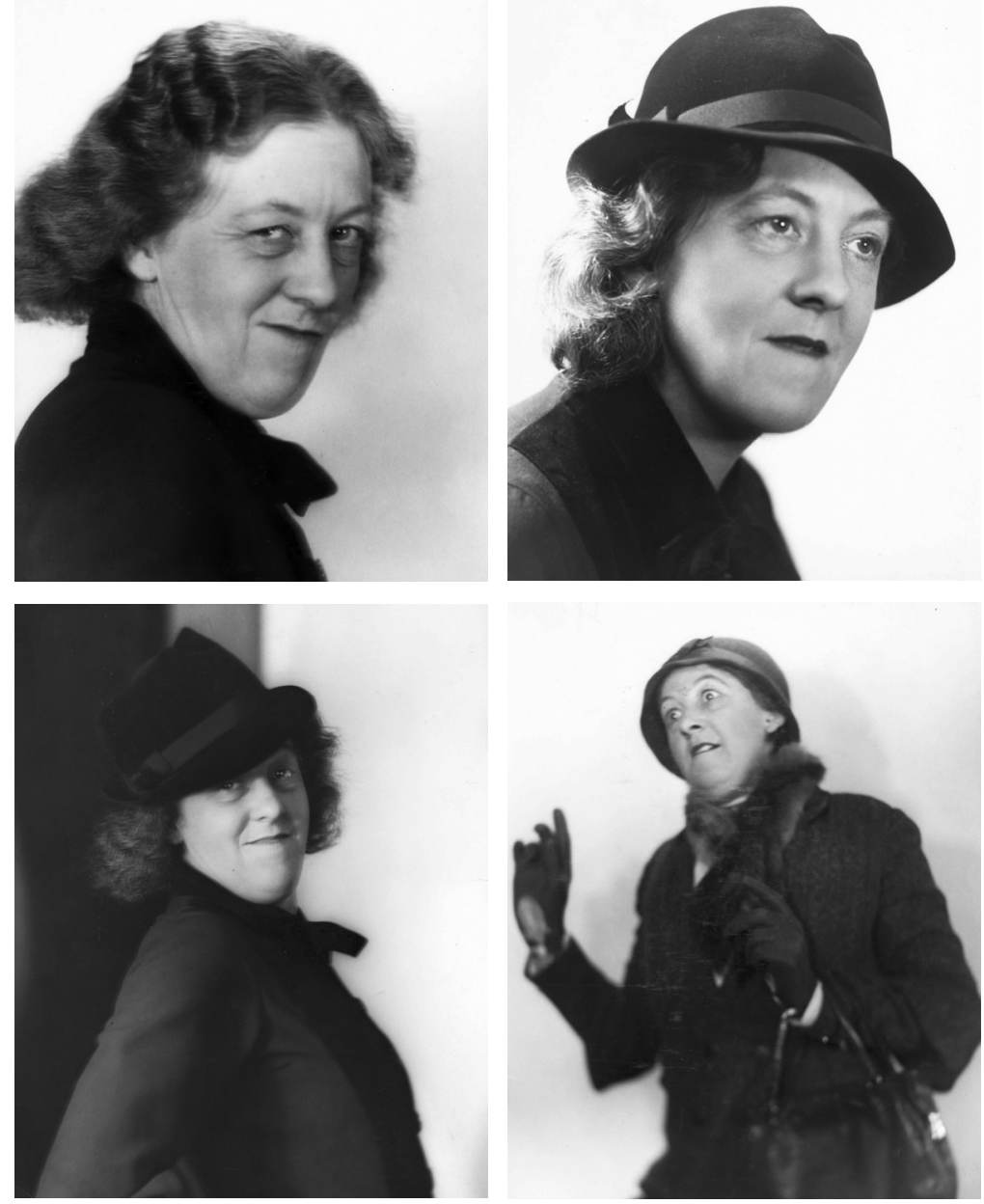

37a-d Sequence of photographs taken in 1935: the costume in which Margaret Rutherford gave her audition for first West End appearance in Hervey House, 1935, at Her Majesty's Theatre.

action takes place on board a ship captured by the Germans. Rutherford is a noisy upper-class woman, a gossip with a taste for cliché who gets most things wrong, but is basically on the right side. When she deliberately trips up a German who calls her an 'old sow' (in German), she shows herself to be more courageous that her male companion, a veteran 
soldier. (In her autobiography Rutherford claims that the kick was her own invention: 'my own statement on how I felt about everything to do with the war' [Rutherford and Robyns, 1972: 83]). On her return, she commences selling her house in Berkeley Square and moving to Balham, so there's also an atmosphere of inter-class solidarity. Finally, English without Tears (1944), scripted by Terence Rattigan and Anatole de Grunwald, shifts from an unspecified pre-war date to 1940. Rutherford is Lady Cristobel Beauclerk, an aristocrat who campaigns for the protection of British migrating birds (though described as an 'old bird' herself). On a trip to the League of Nations to argue her case she finds herself confronted by international mayhem. Flash forward to 1940 and she is accommodating foreign refugees in her grand house - now known as 'The Sanctuary' - a lesson to the country as a whole.

A constant feature in these wartime films and plays, the eccentric woman became representative of the supposed British spirit, at times even Churchillian. In the films she made a little later on, Rutherford's leadership, although remaining endearing, was more open to mockery and yet more strongly feminised. When the eccentric woman meets an eccentric man in a battle for control, it is the eccentric woman who invariably wins. The opponent might be a theatre director who pours scorn on the play she has written (as in Curtain Up, 1952) or a headmaster who expects a headmistress to fall into line during a crisis. John Dighton's popular farce The Happiest Days of Your Life, which opened at the Apollo on 29 March 1948 and was later filmed, takes place in a boys' boarding school. The time is presumably the present but clearly harks back to the recent wartime past. A girls' school is billeted by an incompetent 'Ministry of Evacuation' on a boys' establishment; Rutherford, who is given top billing, is the headmistress, Miss Whitchurch, 'a formidable woman of about fifty, severely dressed in travelling clothes'. When her transplanted school is threatened by a visit from a group of parents, she has to conceal the fact that the sexes are living together in close proximity. At first at severe odds with her opposite number, the head of the boys' school which is undergoing an inspection, she eventually links up with him to outwit their common enemies with a series of lies and increasingly chaotic semi-military manoeuvres.

Much of this is in the tradition of Will Hay's schoolmaster sketches and Ian Hay's comedy Housemaster (1936, filmed in 1938). Indeed, as the critic J. C. Trewin said, one can confidently expect the boys to end up at St Olde's, the Oxford college in Charley's Aunt (Trewin, 1949: 10). Nevertheless, the play has its own distinct frame of reference. While 


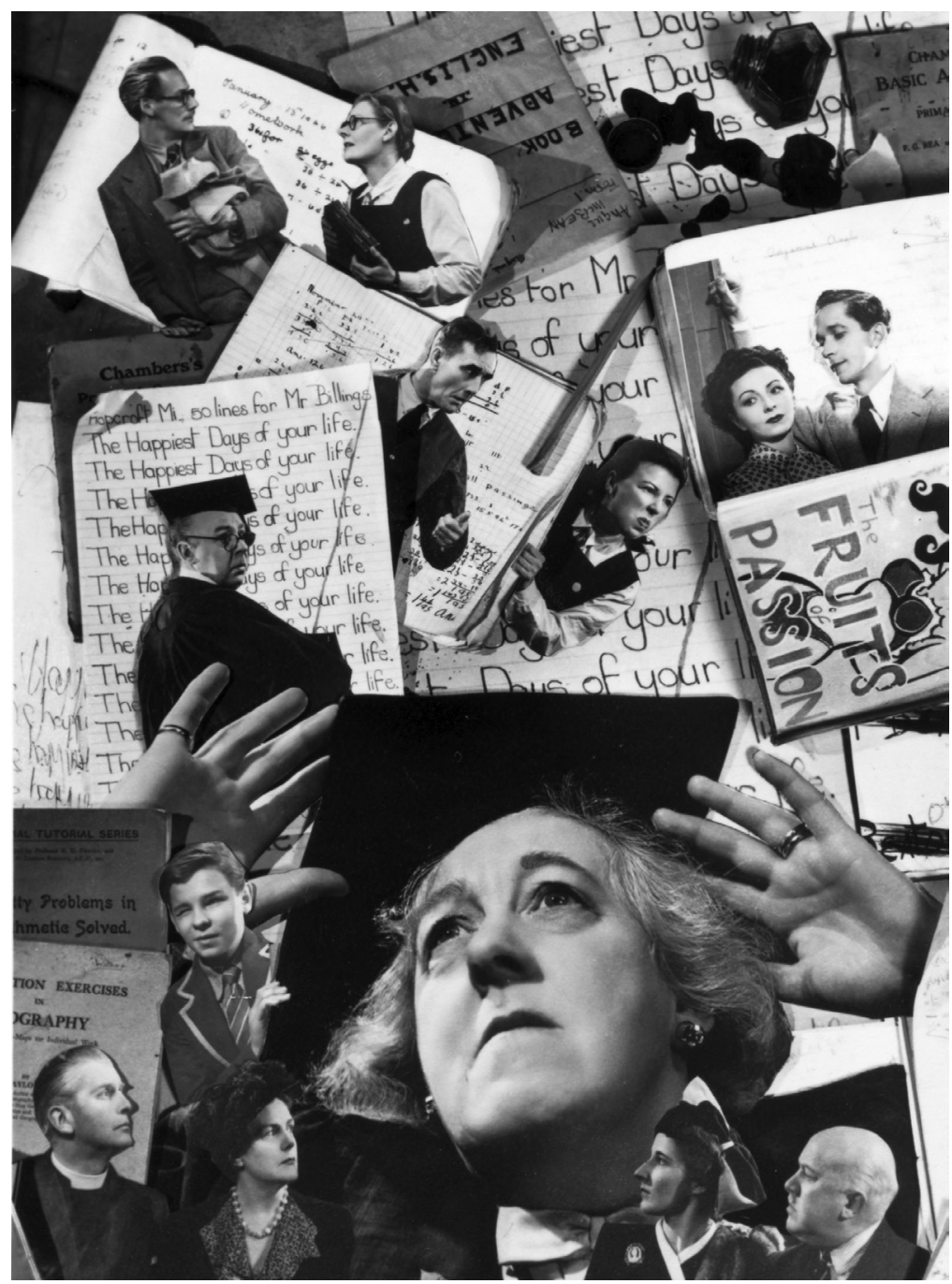

38 A montage of images from The Happiest Days of Your Life, 1948.

harking back to the wartime period of compulsory evacuation of children, it mocks the officious bureaucracy that for some marked the early years of the welfare state and the 'men from the ministry'. 'Muddling through' is, of course, the underlying motif. The film, released in 1950, 
makes the post-war environment much more explicit, with references to rationing, the black market, petrol coupons and nationalisation of the railways. The kitchen staff walk out, a reminder that this was also an age of strikes. When Rutherford takes the initiative, she is still like a military or political leader, either 'battle axe or Amazon' (a phrase that occurs), although capable of blackmail. In the film version the part of the headmaster was played by Alastair Sim, which pitted her masculine forcefulness, however manic, against his feminine dithering. At one point Sim actually becomes her secretary, taking down dictation. In this respect Happiest Days looked forward to the popular St Trinian's series and, in fact, its opening titles are by the cartoonist Ronald Searle. At the end of the film, very different from the play, Rutherford and Sim are romantically hand in hand. She mentions going to work on the 'ground-nuts scheme': the famously ill-fated project developed by the Labour government to grow peanuts on a massive scale in Africa. Their joint future, although a touching thought, seems less than assured.

Alastair Sim's wife, Naomi, recalls the comic partnership between Rutherford and her husband in this way:

They matched each other perfectly during their scenes together when you felt that their mutual anger might cause them to ignite at any minute. I always felt that those two had a lot in common in that their playing of anything at all was so highly individual. You couldn't employ a Margaret Rutherford 'type' or an Alastair Sim 'type'. (Sim, 1987: 132)

Her point is astute. As an actress Rutherford almost always managed to take the lead by responding to others, acting alongside or sometimes against established male actors such as Sim and Robert Morley, as well as younger men, up-and-coming comedians such as Frankie Howerd and Norman Wisdom, who carried music-hall stereotypes over to radio, cinema and, at least for a while, television. An air of gender competition, though usually resolved, permeates the comedy at the level of performance.

Teachers and other authority figures often feature in these later films. In Passport to Pimlico (1949) Rutherford's Professor Hatton-Jones, Professor of History at London University, is an authoritative bluestocking obsessed with her subject, who is required to deliver a lecture which she does in fine declamatory style, making her both 'dotty' and brilliant at one and the same time. In The Runaway Bus (1954) Rutherford is an adherent of 'positive thought' who pronounces that 'negative thought can do nothing. Positive thought can do anything.' At the same time the roles 
became increasingly benevolent, sometimes downright philanthropic. In Miss Robin Hood (1952) Rutherford is a spinster schoolmistress, Heather Honey, who runs a school in Hampstead and wants to free children from boring teaching, and organises resistance against a wicked press baron determined to fire a popular children's writer who, like Honey, believes in a 'kind, sunshiny world'. What is perhaps the best example of the genre, Aunt Clara (1954), has a pre-credit sequence showing film of the Blitz, but turns out to be a version of the good angel myth. Aunt Clara (Rutherford) inherits the estate of her corrupt uncle Simon and sets about redistributing it among those who he had abused in life. The underlying joke is that as Clara investigates the shady world of his past, so she is obliged to appear less socially perceptive than she really is. In the end she manages to help some ill-treated racing greyhounds (Simon was a gambler) and a household of prostitutes (Simon was a regular patron). Terminally ill - a fact she has kept from others - Aunt Clara has a 'saintly' death, and in the closing sequence appears complete with angelic wings. Even in the Norman Wisdom vehicle Just my Luck (1957), Rutherford's character is Mrs Dooley, a rich Irish widow who lives with an ape and an elephant among other creatures, races her horse merely for exercise, not for money, and calls her pets her 'children'. By the end of the 1950 s the war had begun to be presented not so much as a recent reality as an increasingly distant backdrop. I'm All Right Jack (1959), directed by John and Roy Boulting, a famous satire in its day, opens with documentary footage from 1945 featuring Churchill. Rutherford is the aunt of the upper-class ingénu who has found himself involved in a conflict between trades unionists and their bosses (both equally corrupt). Aunt Dolly hates the working class - 'all muscles and sweat' - as well as the 'horrid unions', but nevertheless bonds with the wife of the main union leader. Female common sense almost wins out, though not quite. 'What a nation we are when stirred!': Aunt Dolly's patriotic belief is not enough to counteract the concluding vision of national chaos.

Certain basic structural principles are at work throughout these films, constituents of a national self-image, which includes, of course, relationships between genders and classes. Invariably there is a romantic young couple, too young to have served in the war, bright, energetic and sincere, whose minor sub-plot carries on in tandem with a farcical main story. There is frequently a comic bureaucracy of some kind, a genial swipe at the red tape of the new welfare state, against which Rutherford is likely to be pitted. Nevertheless, it would be wrong to see her career as given over entirely to such engagingly 'dotty' and socially anarchic roles 
during this period. She participated in the fashion for contemporary French drama, Anouilh in particular, and doubled with Sybil Thorndike as the White Queen in a dramatisation of Alice in Wonderland in 1944. In 1945 she appeared in Ivor Novello's wildly romantic Perchance to Dream. As a film actress, she had by the 1960 s achieved a level of international stardom that led to vignettes in major releases including The V.I.P.s (1963) for which she received an Academy Award for best supporting actress, and Chaplin's The Countess from Hong Kong (1967).

It was at this latish period in her career that Rutherford also took on stage roles, all of them unaccommodated women of one kind or another, associated with Restoration and eighteenth-century comedy. This was a repertoire that had steadily gained in respect and popularity in the course of the century. There were four roles in particular: Lady Wishfort in Congreve's The Way of the World (Lyric Hammersmith, 1953, and Saville, 1956); Mrs Candour in Sheridan's The School for Scandal (Haymarket, 1962); Mrs Heidelberg in The Clandestine Marriage by George Colman the Younger and David Garrick (Chichester, 1966); and Mrs Malaprop in Sheridan's The Rivals (Haymarket, 1966). Although comic, these women have it in common that they are either outside the family altogether or uncomfortably within it, the difference from her more recent film parts being that they all lack the element of generosity. This caused problems in reception and probably in Rutherford's actual performances as well.

Her Lady Wishfort of 1953 was generally praised, although it is clear from the reviews that she was dogged with a reputation as well as a physique. Kenneth Tynan's celebrated notice in the Evening Standard (Tynan, 1953: 11) carried the headline 'Miss Rutherford's Chin Steals the Show'. Time and again critical metaphors tell the same comic story, betraying an obsession with physical appearance above all else: 'like a marquee in a high wind' (Barber, 1953: 3), 'a Tenniel drawing of the Red Queen repeated in delectable sugar candy' (Anon., 1953: 2), 'a splendidly padded windmill' (Keown, 1953: 305). When she returned to the role in 1956, the pivotal year of Look Back in Anger and of the visit to London by Brecht's Berliner Ensemble, critics were now more wary of the mixture of scenic luxury and mildly camp innuendo favoured in the West End productions of H. M. Tennent. Along with other members of the company, Rutherford suffered in her turn. For Milton Shulman, never a great admirer, 'Miss Margaret Rutherford, looking like an abandoned stone quarry as Lady Wishfort, has some extremely comic moments but lacks a little of the healthy lasciviousness the part demands' (Shulman, 1956: 12). Even more damagingly, her film successes now threatened 
her integrity on stage. So, for instance, 'Margaret Rutherford, though quite unlike the scheming Lady Wishfort of Congreve's cruel imagining, cleverly substitutes in place of that greedy old fribble her own well-loved study of a hard-breathing headmistress' (Hope-Wallace, 1956: 5).

When she undertook the gossipy Mrs Candour in The School for Scandal in 1962 in yet another Tennent production directed by Gielgud, Tynan, unexpectedly tolerant of the show's typically 'spirited opulence', did manage to find darker depths in Rutherford's performance and chose a remarkably shocking simile to match the role's own double entendres: 'Margaret Rutherford as Mrs. Candour, warming to the task of character assassination like a midwife beneath whose benevolent exterior there beats an abortionist's heart' (Tynan, 1962: 28). So, for one critic at least, it does seem that on this occasion, and in this part, Rutherford did manage to achieve a level of malice - and bawdy - that she was rarely called upon to risk. (Interestingly, she had first attempted the part back in 1932 in a small off West End production.) Nevertheless, her final classic roles on stage were in general less fortuitous, a combination of ill-health, increasing age and antiquated production styles making her vulnerable to critical impatience. A rougher kind of realism was beginning to replace what Tynan called the 'high polite comedy' of the repertoire previously associated with the Restoration. The signal production was William Gaskill's The Recruiting Officer at the National Theatre in 1963. At Chichester in 1966, in her seventies, she played opposite Alastair Sim in The Clandestine Marriage by George Colman and David Garrick, which, although originating from 1766, has a good deal in common with Restoration comedy. Once again Rutherford played an aunt, the snobbish Mrs Heidelberg. But a perception of datedness pervades the critical appreciation

Just as there is no definitive performance, so there is no definitive response. Nonetheless, an overall atmosphere of irritation and disquiet begins to characterise these 1960 s reviews. At a time when - thanks to the Royal Shakespeare Company and the new National Theatre - the idea of an integrated company was dominant, unashamedly star-based productions looked unbalanced. As styles and conditions changed, so new demands were made of the actor. No performer, however idiosyncratic, is ever immune to this cruel rule and, in a way, Rutherford became victim of her own eminence. She is even said to have curtsied to meet the applause at her first entrance, which was very old-fashioned behaviour indeed (Barker, 1966: 7). By contrast film critics tended to enjoy her presence quite separately from the narrative in which she was appearing. The 
Miss Marple films of the early 196os were very good box office, even if Agatha Christie is said to have been unhappy with the farcical element in Rutherford's interpretation.

To suggest that Margaret Rutherford in her prime belonged to her age, part as much as product, implies no disrespect, nor does it deny her capacity to entertain even today. Fortunately some of her most authentic work between, say, 1938 and 1959 remains preserved on film and in the words of her more discriminating critics. Hers was a unique, at times heroic, individual achievement and yet, in addition, in the roles for which she was best known, she left a record of changing social conditions as they affected single women in the mid-twentieth century. Initially a left-over, the much maligned yet unavoidable 'spinster' of the 1920s, in the 1940 s she took on characters whose conduct was determined by the immediacy of conflict; in the aftermath, the 1950s, she came to stand for a form of moral intransigence. Although her voice had a class inflection and class was at the heart of many of the comedies in which she appeared - it took its moral authority from female resilience. Often frustrated, her gestures were always exact.

\section{References}

Agate, James (1938), 'Irish Without Tears', Sunday Times, 5 June, p. 4.

Agate, James (1941), 'Mr. Coward's New Play', Sunday Times, 6 July, p. 2.

Anon. (1953), 'Lyric Theatre, Hammersmith', The Times, 20 February, p. 2.

Anon. (1956), 'Saville Theatre', The Times, 7 December, p. 3.

Avery, C. R. (1935), 'Hervey House', Observer, 19 May, p. 15.

Barber, John (1953), 'Pamela - Rogue in Gossamer', Daily Express, 20 February, p. 3 .

Barker, Clive, and Maggie B. Gale, eds (200o), British Theatre between the Wars, 1918-1939, Cambridge: Cambridge University Press.

Barker, Felix (1953), 'At the Theatre. Fine Matters', Observer, 22 February, p. 11.

Barker, Felix (1966), 'The "News" Critics', Evening News, 2 June, p. 7.

Brown, Ivor (1935), 'Last Night's Play', Observer, 3 November, p. 22.

Brown, Ivor (1938), 'This Week's Theatres. Spring Meeting', Observer, 5 June, p. 11.

Brown, Ivor (1939), 'This Week's Theatre. The Importance of Being Earnest', Observer, 20 August, p. 9.

Brown, Ivor (1941), 'At the Play', Observer, 6 July, p. 7.

Bryden, Ronald (1966a), 'Bulls-eye at the Rag-bag Junction', Observer, 5 June, p. 25.

Bryden, Ronald (1966b), 'Villains of a Vicious Circus', Observer, 9 October, p. 24. 
Darlington, W. A. (1956), 'Kay Hammond Unsuccessful as Millamant', Daily Telegraph, 7 December, p. 10.

Farrell, Molly J., and John Perry (1938), Spring Meeting, London: Collins.

Feigel, Lara (2010), Literature, Cinema and Politics 1930-1945: Reading Between the Frames, Edinburgh: Edinburgh University Press.

Gale, Maggie B. (1996), West End Women: Women and the London Stage 19181962, London: Routledge.

Hobson, Harold (1953), 'Player's Hurdle', Sunday Times, 22 February, p. 9.

Hope-Wallace, Philip (1953), “"The Way of the World”. Revival by Gielgud', Manchester Guardian, 20 February, p. 5.

Hope-Wallace, Philip (1956), 'Congreve at the Saville', Manchester Guardian, 8 December, p. 5.

Hope-Wallace, Philip (1966), 'The Rivals at the Haymarket', Guardian, 7 October.

Huggett, Richard (1989), Binkie, Eminence Grise of the West End Theatre 19331973, London: Hodder and Stoughton.

Jeffreys, Sheila (1985), The Spinster and Her Enemies: Feminism and Sexuality 1880-1930, London: Pandora.

Jones, Mervyn (1959), 'South American Casino', Observer, 7 June, p. 22.

Keown, Eric (1953), 'At the Play', Punch, 4 March, p. 305.

Keown, Eric (1956), Margaret Rutherford, London: Rockliff.

Kretzmer, Herbert (1966), 'Rutherford, Richardson ... a Must for the Devotees', Daily Express, 7 October, p. 4.

Macnab, Geoffrey (2000), Searching for Stars: Rethinking British Cinema, London: Cassell.

Merriman, Andy (2009), Margaret Rutherford: Dreadnought with Good Manners, London: Aurum Press.

Nicholson, Virginia (2007), Singled Out: How Two Million Women Survived Without Men After the First World War, London: Viking.

Rutherford, Margaret, and Gwen Robyns (1972), Margaret Rutherford, An Autobiography as told to Gwen Robyns, London: W.H. Allen.

Seyler, Athene, with Stephen Haggard (2013), The Craft of Comedy. The 21st Century Edition, ed. Robert Barton, London and New York: Routledge.

Shulman, Milton (1956), 'Mr Clements Loses his Touch', Evening Standard, 7 December, p. 12.

Sim, Naomi (1987), Dance and Skylark: Fifty Years with Alastair Sim, London: Bloomsbury.

Sutherland, Lucie (2007), 'The Actress and the Profession: Training in England in the Twentieth Century', in Maggie B. Gale and John Stokes, eds, The Cambridge Companion to the Actress, Cambridge: Cambridge University Press, pp. 95-115.

Tóibín, Colm (2011), 'The Importance of Aunts' (in the nineteenth-century novel), London Review of Books, 33.6, 17 March, pp. 13-19.

Trewin, J. C. (1949), Plays of the Year, 1948-49, London: Paul Elek. 
Tynan, Kenneth (1953), 'Miss Rutherford's Chin Steals the Show', Evening Standard, 20 February, p. 11. Repr. in Curtains: Selections from the Drama Criticism and Related Writings, London: Longmans, 1961, pp. 38-9.

Tynan, Kenneth (1956), 'Second-Best Bed', Observer, 9 December, p. 11.

Tynan, Kenneth (1962), 'Turnout for the First Eleven', Observer, 8 April, p. 28.

\section{Archives}

Margaret Rutherford Biographical File, Victoria and Albert Museum, London Powell, Dilys, et al., 'The Art of Margaret Rutherford', broadcast on Radio 3 on 10 December 1975. Sound recording available at Sound Archive, British Library $\mathrm{NP}_{2} 653$ 